\title{
Inolvidable, Luis
}

\section{Roberto Retamoso}

Luis Giunípero fue mi analista prácticamente hasta el momento de su muerte. Esa extraña coincidencia, esa sincronía sorprendente, habla a las claras de las ignotas razones que se aúnan para tramar ciertas constelaciones de hechos tan enigmáticas como felices.

Quisiera hablar, entonces, de Luis como analista. Pero no de manera genérica y objetiva, al modo de quien pinta una semblanza, sino hablando de quien fuera el analista mío. Dicho lo cual, queda expuesto el sentido problemático del adjetivo posesivo, que significa pertenencia. Porque, ¿qué significa decir que haya sido el analista mío?... ¿Que me perteneció?... ¿Que formaba parte de ese dominio incierto e impreciso al que llamamos mi mundo?... ¿Que tributaba al afán narcisista con que un Yo caprichoso pretendía hacerse de aquello que lo rodeaba?...

Obviamente, la respuesta es no. Ello no impide, de todas maneras, que uno siga diciendo mi analista. La razón, en todo caso, habría que buscarla en los efectos de un dispositivo sabiamente articulado por él, donde yo me entregaba a la intrigante búsqueda de un pasado perdido, al que debía encontrar para entender mi presente.

Y no sólo entenderlo. Debería agregar, con rigor, con justicia, para poder modificarlo.

Siempre me sorprendió el pensar que uno pueda modificarse. Porque siempre creí que se modifica el entorno, que se modifica eso que llamamos, de manera cómoda, la realidad, pero me costó más aceptar que alguien pueda modificarse a sí mismo.

Con Luis aprendí que eso es posible. No estoy hablando de cualquier tipo de modificación -es sabido que hay cuestiones arcaicas, estructurales, que suelen ser inmodificables- sino de aquellos cambios que transforman nuestra relación con las cosas.

A esto no quiero decirlo de manera abstracta. Por el contrario, quiero decirlo de manera concreta, refiriendo a un trabajo que permite deconstruir los efectos dolorosos de nuestros propios síntomas, para dar paso a un deseo sometido hasta entonces por lo superyoico. 
Estoy diciendo aprendí. La expresión puede ser discutible, pero para mí el análisis con Luis tenía esa dimensión de lo que se aprende porque alguien lo enseña, aunque no haya en el sitio maestro alguno. No sólo maestro: tampoco una figura otra, ya que el lugar que Luis ocupaba más bien parecía hallarse en ese Otro lado que a todos nos habita, precisamente porque nos constituye.

Todo ello se encarnaba, se animaba, en un diálogo amable donde lo que predominaba era un humor sano, alegre. Recuerdo que Luis hacía uso y gala de un humor proverbial cuando hablaba, de un humor sutil que era asimismo gracioso. Con ese humor lograba cosas magníficas, porque gracias a él le quitaba dramatismo a mis cosas. Más de una vez pensé en una suerte de tópica donde situar el habla humorística de Luis, y esa tópica terminaba siendo la que propuso Aristóteles para clasificar los géneros poéticos. Planteando como coordenadas la naturaleza del objeto representado -acciones elevadas o bajas de los personajes- y el modo del discurso -la narración épica o la representación dramática-, Aristóteles reconocía cuatro géneros poéticos, la tragedia y la epopeya para referir las acciones elevadas, y la comedia y la sátira para representar a las acciones bajas.

La tradición de Occidente, su moral, su estética y su política, siempre hicieron de lo trágico y lo épico los modos excelsos de la poesía. Los otros dos, por el contrario, siempre fueron confinados al lugar degradado, devaluado, de los géneros menores.

No sé si eso es efectivamente así, o no es más que una construcción cultural mentirosa hecha por hombres débiles dotados de un poder real, como quería Nietzsche.

Lo que sé es que Luis elegía ese lugar, el de las voces sarcásticas -levemente, dignamente sarcásticas si la expresión vale- para operar sobre un imaginario que hacía obstáculo. Lograba, de tal modo, que un sujeto -yo en este caso- pudiese pensar sus fantasías, visualizar sus fantasmas, reconocer su deseo, sin temor, sin vergüenza, sin culpa. Era, como Sócrates, partero de la verdad, pero no de cualquiera. Porque aquella no era una verdad común, compartida, sino una verdad singular, y por ello tremendamente más poderosa: la nuestra. 